\title{
A SNOW-BANK PUSH MECHANISM FOR THE FORMATION OF SOME "ANNUAL" MORAINE RIDGES
}

\author{
By Righard V. Birnie \\ (Department of Geography, University of Aberdeen, Aberdeen AB9 2UF, Scotland)
}

\begin{abstract}
Ice-marginal features in South Georgia include minor moraine ridges running approximately parallel to the ice margin and developed as superficial forms in various depths of till. It is suggested that these developed as ice-contact landforms, some being created by the interaction of the ice edge and abutting marginal snow bank, whilst the glacier is advancing. This advance is essentially short-term, being part of a seasonal variation in the position of the ice margin. "Snow-bank push" is the term proposed to describe this mechanism of ridge formation.

RÉsumé. Un mécanisme par congère de poussée pour la formation des ondulations morainiques "annuelles". La morphologie périglaciaire en South Georgia inclue de petites ondulations morainiques allongées, approximativement parallèles à la bordure de la glace, et qui se développent comme des formes superficielles dans des dépôts de profondeurs variées. On suggère que ces ondulations se sont développées comme des formes de contact avec la glace, par l'interaction de la limite de la glace et de la congère de neige qui s'adossait à la glace le long de cette limite, pendant que le glacier avançait. Cette avance est essentiellement temporaire, étant une partie d'une variation saisonnière dans la position du front. "Congère de poussée" est le terme proposé pour décrire ce mécanisme de formation d'ondulation.
\end{abstract}

Zusammenfassung. Ein "Snow-bank push" [Schneewall-Schiebe-] Mechanismus für die Bildung "jährlicher" Moränenwälle. Zu den Erscheinungen an Eisrändern in South Georgia gehören kleinere Moränenwälle, die annähernd parallel zum Eisrand verlaufen und als Oberflächenformen in verschieden mächtigem Glazialschutt entwickelt sind. Es wird vermutet, dass sie sich als Geländeformen unter Eiskontakt gebildet haben, wobei einige durch die Wechselwirkung zwischen dem Eisrand und der angrenzenden Schneedecke während des Vorrückens des Gletschers entstanden sind. Ein solches Vorrücken ist seinem Wesen nach kurzfristig, nämlich eine Phase der jahreszeitlichen Schwankungen der Eisrandlage. Als Name für den Bildungsmechanismus der Wälle wird "Snow-bank push" vorgeschlagen.

\section{INTRODUCTION}

The ice-marginal environments of many land-terminating glaciers in South Georgia display complex patterns of minor moraine ridges. Clapperton (1971), in his general geomorphological study suggested that both "shear" and "squeeze" mechanisms may be involved as an explanation for these ridge forms. The aim of this paper is to evaluate these ideas on the basis of results obtained during the austral summer 1974-75, placing special emphasis on a hitherto unrecorded mechanism for South Georgia, that of marginal "snow-bank push".

From November 1974 to March 1975 several moraine complexes were studied along the north and north-western coasts of South Georgia during a geomorphological mapping programme in collaboration with the British Antarctic Survey (Fig. I).

South Georgia (lat. $54-55^{\circ}$ S., long. $36-38^{\circ}$ N.) lies south of the Antarctic Convergence in a belt of prevailing westerlies. The island is mountainous and, despite its northerly position, about $58 \%$ of the land area is under ice. This is represented at a whole range of scales from ice domes, like that of the Kohl-Larsen Plateau which is many kilometres across, to a multitude of minor cirque glaciers. The island's climate is typically maritime with a high annual precipitation (mean I $395 \mathrm{~mm}$ of water at Grytviken) and a mean temperature of $+\mathrm{r} .7^{\circ} \mathrm{C}$. The bulk of the glaciers are considered to be temperate, certainly below I ooo m (Smith, 1960), their mass balance being marked by a high positive winter accumulation offset by a high negative summer ablation. There is, therefore, abundant free melt at all levels in the marginal ice mass during the summer months.

\section{General Description}

The pro-glacial moraine complexes of the glaciers visited were developed in till, the dominant landform element comprising low morainic ridges ranging in height from 0.2 to $2.5 \mathrm{~m}$, and lying roughly parallel to the ice margin. A secondary ridge component exists at 


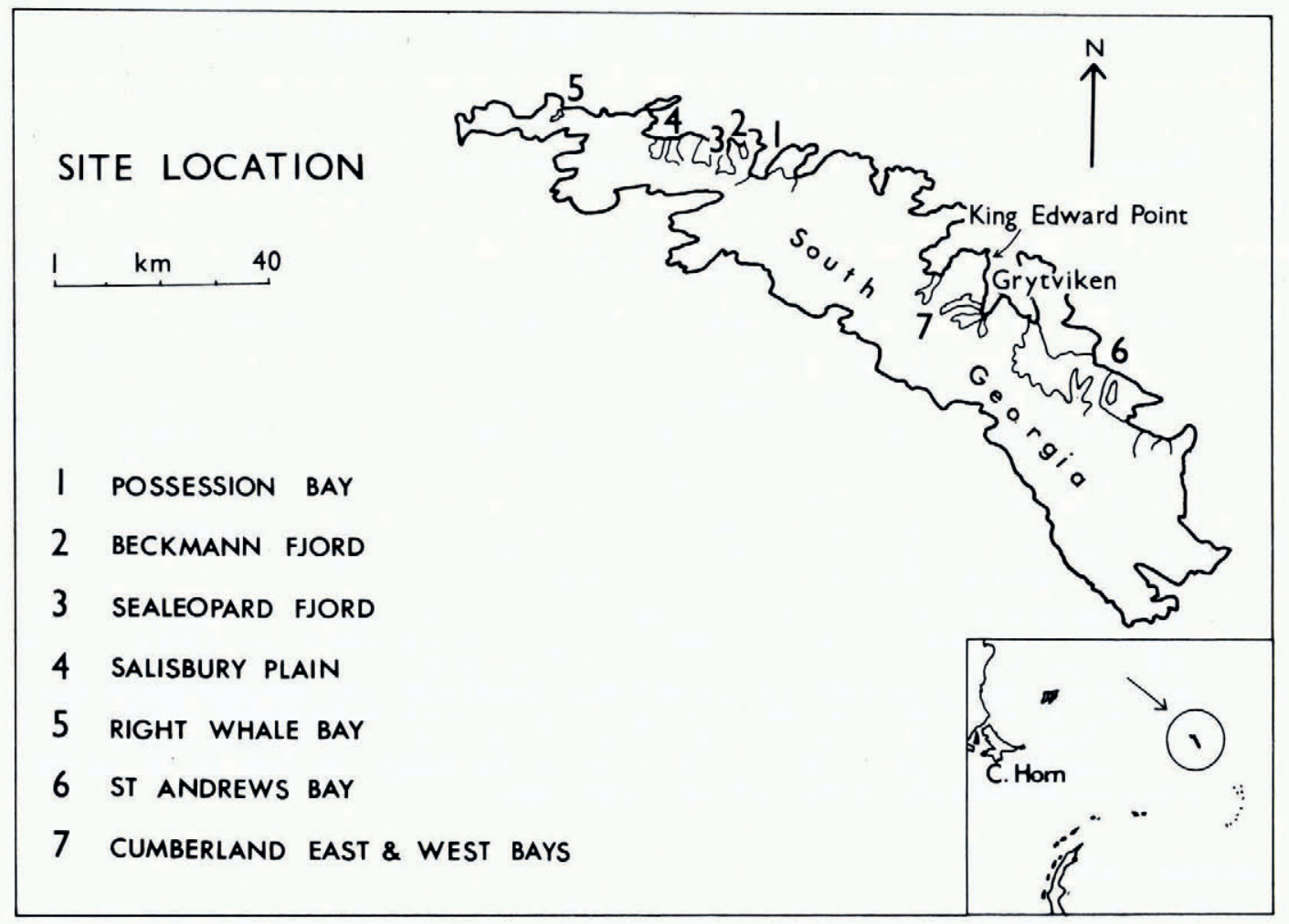

Fig. 1. South Georgia-site location map.

right-angles to the major group and passes between them. Thus, the best-developed moraine complexes, for example at the overspill glacier snout in Sealeopard Fjord, display a reticulate plan form.

More detailed investigation into the forms associated with the major ridge group revealed considerable variation in both plan and cross-section. There is a marked tendency for lobate, or arcuate ridge crests, which are closely related to the configuration of the ice edge (this is especially apparent in the freshest ridges where the ice margin is still in contact). In addition, the fresh ridges may be steep-sided and are often topped by a "cock's-comb" feature, whilst the outer ridges, away from the ice edge, show signs of degradation and slope decline, and they are often broken or submerged by the action of melt water. There is an overall tendency for steeper distal slopes.

In section the ridges are revealed as superficial forms developed in a variety of till covers. The superficial nature of the ridge form should be stressed, for nowhere has deep-rooted disturbance in the till been observed. In one melt-water section a thin layer of washed sands, between 2 and $4 \mathrm{~cm}$ thick, underlay two ridges by $50-75 \mathrm{~cm}$ and cropped out behind a third (Fig. 2).

The bedding of the washed material was well preserved, suggesting that the surrounding till was undisturbed below a depth of $50 \mathrm{~cm}$. A macro-till fabric analysis was undertaken in order to compare the orientation of the clasts within the section. Diagrams were constructed for the till below the sand layer, the till comprising the proximal slope of the left-hand ridge 
(Fig. 2) and the till comprising its distal slope (Fig. 3). The clasts in the deep sample showed strong orientation in the direction of ice movements, whilst those within the ridge showed signs of disturbance and rotation.

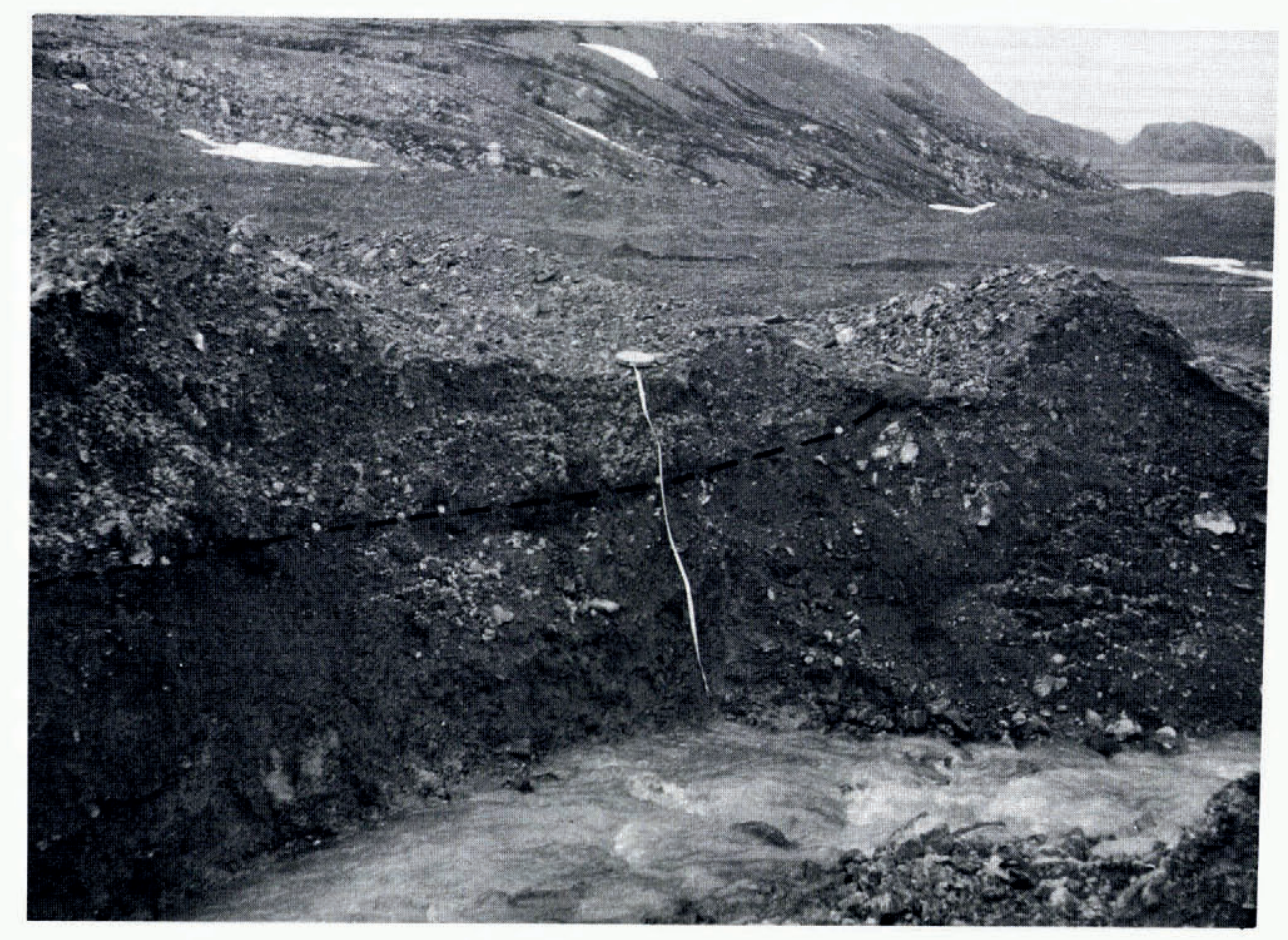

Fig. 2. Till section $1.75 \mathrm{~m}$ deep with thin layer of sands $2-4 \mathrm{~cm}$ thick (indicated by pecked line) underlying the low ridges. The ice edge lies to the left off the photograph.

\section{THE ICE-DEBRIS INTERFAGE}

The zone of contact between the glacier edge and the fronting till surface has been recognized as being of critical importance in the formation of "annual" moraine ridges (Worsley, I974, p. 272). One of the most distinctive features of the ice margins studied is the presence of a pro-glacial snow bank. Ridges with a snow core were excavated early in the season at a site in Possession Bay. As the summer melt progressed, it became apparent that there was often an interaction between the ice edge and the contiguous snow bank. This relationship was seldom simple. For example, along the western edge of Lucas Glacier an overfold was evident in the marginal snow bank (Fig. 4). The limbs of the fold were unequal in length, being 3.5 and $2.2 \mathrm{~m}$ on the proximal and distal sides, respectively. The overfold structure broke down at one point and the dirt-laden bed of the snow bank was revealed. This represented an overthrust structural form, the plane of thrust being at a lower angle than the axis of the overfold. Further along the glacier edge these structures were replaced by a cavity formed by the up-arched snow bank lying against the glacier edge. Thus, within roo $\mathrm{m}$ of the ice margin three distinctive variations in the ice-snow relationship were visible. Similar complexity was common along the margins of most of the glaciers visited. 


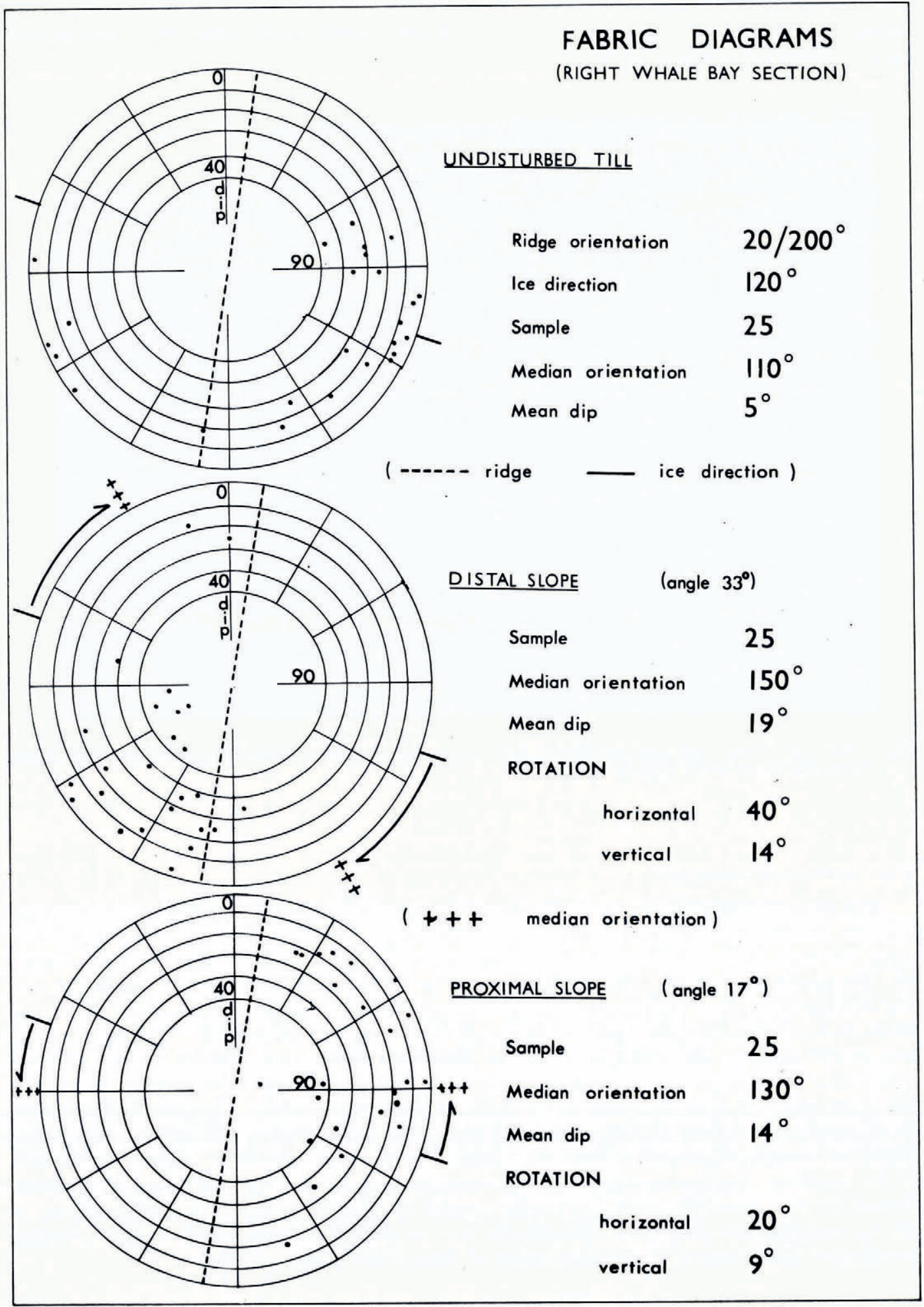

Fig. 3. Till-fabric diagrams for melt-water section, Right Whale Bay. 


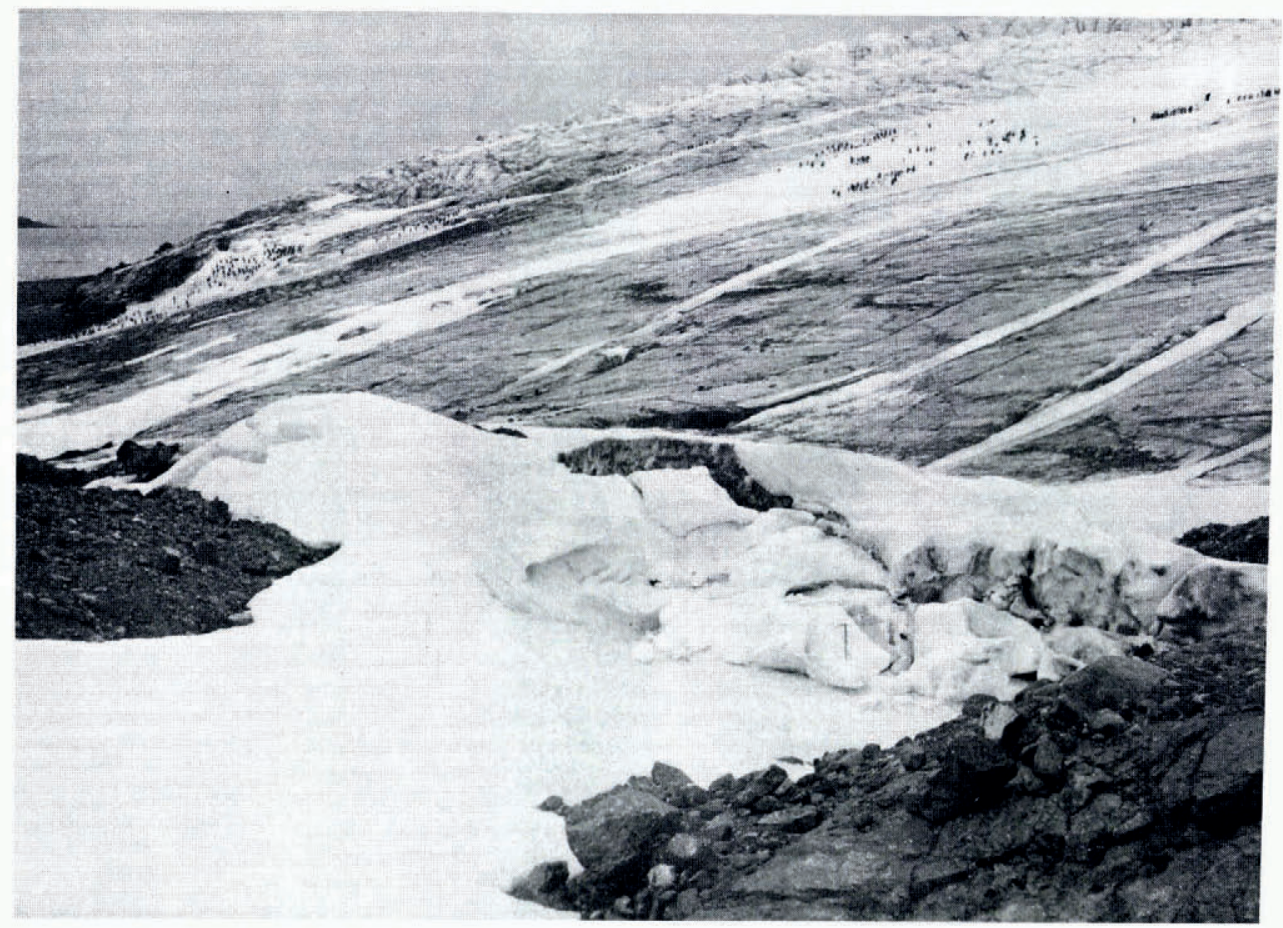

Fig. 4. Snow-bank disturbance along the western edge of Lucas Glacier. Three different relationships may be seen. On the far left the snow bank is up-arched and a cavity exists beneath. In the centre the snow bank is overfolded, whilst towards the right, above the ice-axe, the snow has been overthrust.

In an attempt to elucidate the significance of the snow-bank disturbance on the formation of the moraine ridges, fixed-station photography was undertaken on a small section of the ice margin at one of the glaciers near Ernesto Pass (Right Whale Bay) over a ro d period.

The section of the ice edge chosen showed clearly the distinctive folding of the snow bank (Fig. 5). Ablation had occurred at different rates along the ice margin and, where there had been sufficient melt, a minor till ridge had developed. The objective of the photography was therefore to attempt to trace the way in which the ridge evolved. The section chosen included detail of an actively forming "proto-ridge", about 50-6o cm high. This was contained within the boundaries defined by the upstanding limb of the glacier ice and the simply folded snow bank. As melting continued, the debris that was held in the ice-snow interface lost that support and failure occurred. This debris comprised individual clasts and clasts set in clay matrix which variously rolled, slid, and flowed over the backing ice and fronting snow, covering both to a depth of $5^{-10} \mathrm{~cm}$. This had the effect of slowing down their rate of melt, whilst the bare ice backing the "proto-ridge" continued to ablate rapidly. At the end of the Io $\mathrm{d}$ period the section had become separated from the glacier and the ice edge had retreated $2.4 \mathrm{~m}$. During that period the buried snow and ice on either side of the "proto-ridge" gradually ablated, the snow melting more rapidly. This had the effect of letting down the mantling debris on to the "moulded" material beneath. Thus, the final ridge form comprised a central core of material which had filled the area beneath and between the ice and the snow bank, upon which lay a thin mantle of disturbed loose material deposited by the ablation of the ice and snow bodies. (This developmental sequence is depicted in Figure 6A.) The shape of the final ridge form is therefore closely related to the dimensions of the ice-snow interface and its cross-sectional character. 


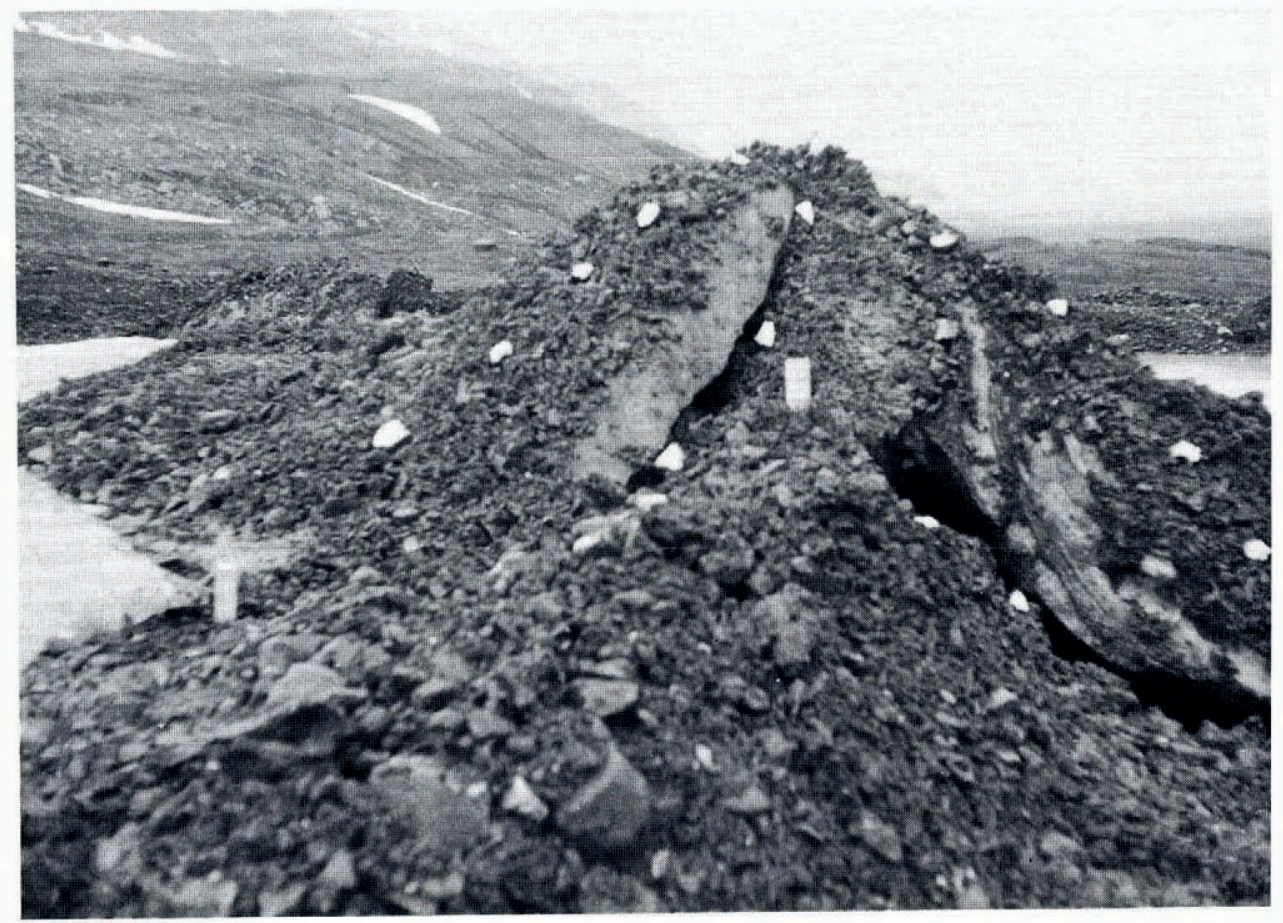

Fig. 5. The process of ridge formation. The ice edge lies to the left, whilst on the right the folding of the snow bank is clearly displayed by the depositional layering. Painted clasts were used to trace material movement as the ridge evolved.

The appearance of these moraine ridges created by the interaction of the ice edge and the marginal snow bank is influenced by several factors. Primarily, the exact ice-marginal relationship (in terms of the cross-sectional area and the ice-snow depths) together with the topographic setting may account for much of the observed diversity. Cross-sectional evidence from several sites has been combined in an attempt to show how these factors operate (Fig. $6 \mathrm{~B})$. The detail of the ice-snow interface shows how the size and character of the contact may influence the resultant form. Where it is thin, both the ice and the snow bank tend to be up-arched in a simple fashion (e.g. the Right Whale Bay site). However, where there is a deep contact face, the snow bank will be folded or overthrust without equivalent disturbance in the ice mass. This fundamental variability in snow depth, ice-edge thickness, till character and local topography results in a whole range of interactions and resultant forms.

There are several other minor topographic features associated with this ridge type, particularly with the snow bank itself. As the marginal snow bank retreats towards the ice edge, its former limits are marked by very small ridges in the mobile till surface. These minor "squeeze" forms apparently result from instability in the till caused by the load differentials of the ablating overburden. They range from 5 to $20 \mathrm{~cm}$ in height and appear to be shortlived features, their occurrence being restricted to the freshest moraine exposures. Several sites also revealed a pattern of parallel "flutes" on the till surface beneath the ablating snow bank, at approximately right-angles to the ice edge. These were formed under the snow bank as it was "pushed" forward during the advance of the ice margin (Fig. 7). These "flutes" have a secondary origin and are not primary depositional forms of direct glacial action. Their persistence as marginal features is, like the snow-bank "squeeze" ridges, temporary. 


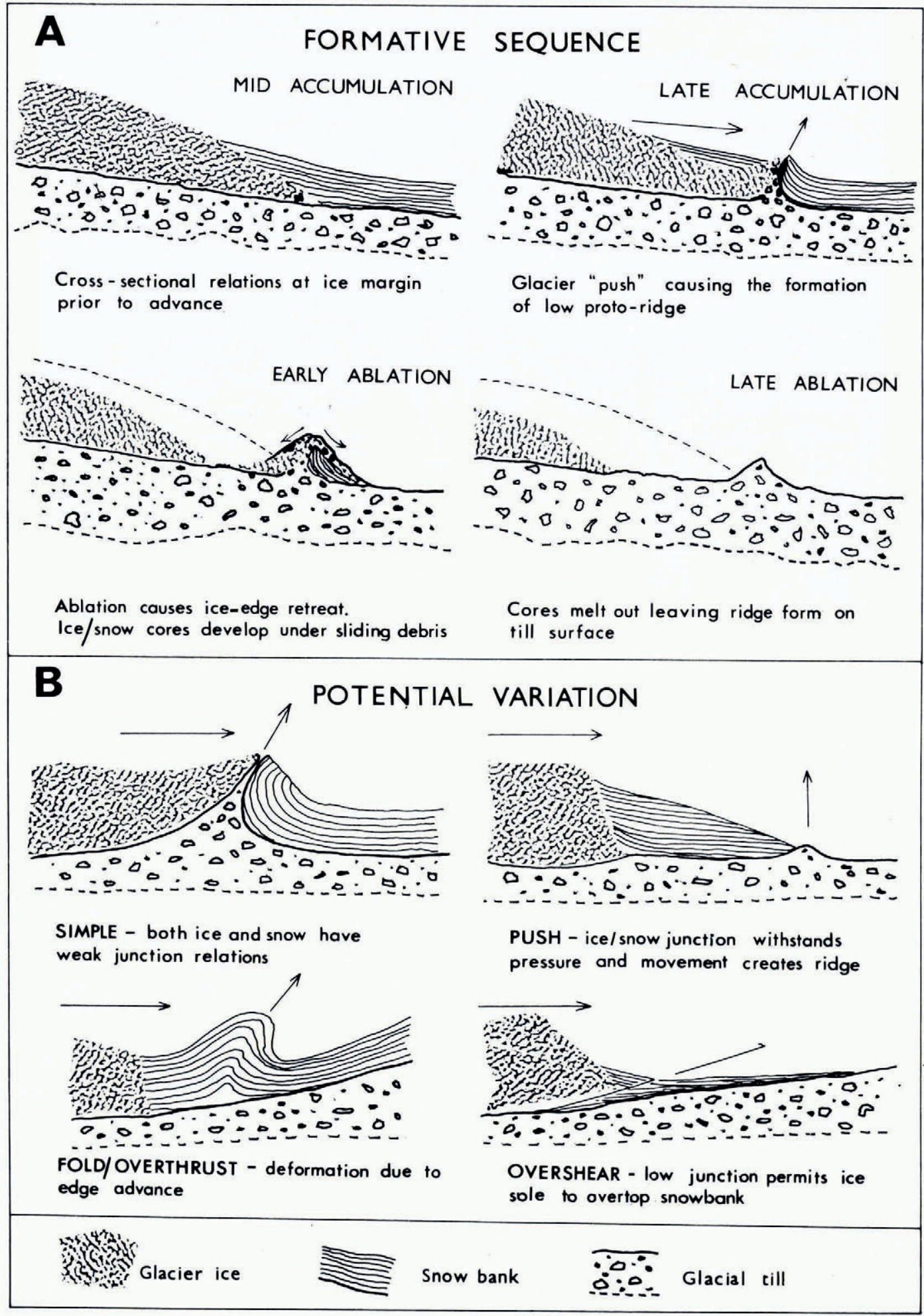

Fig. 6. A. Development of a "snow-bank push" ridge. The development sequence outlined above is idealized from the relations between the ice edge and snow bank observed at the Right Whale Bay site. B. Variations in the ice-snow-bank interactions. 


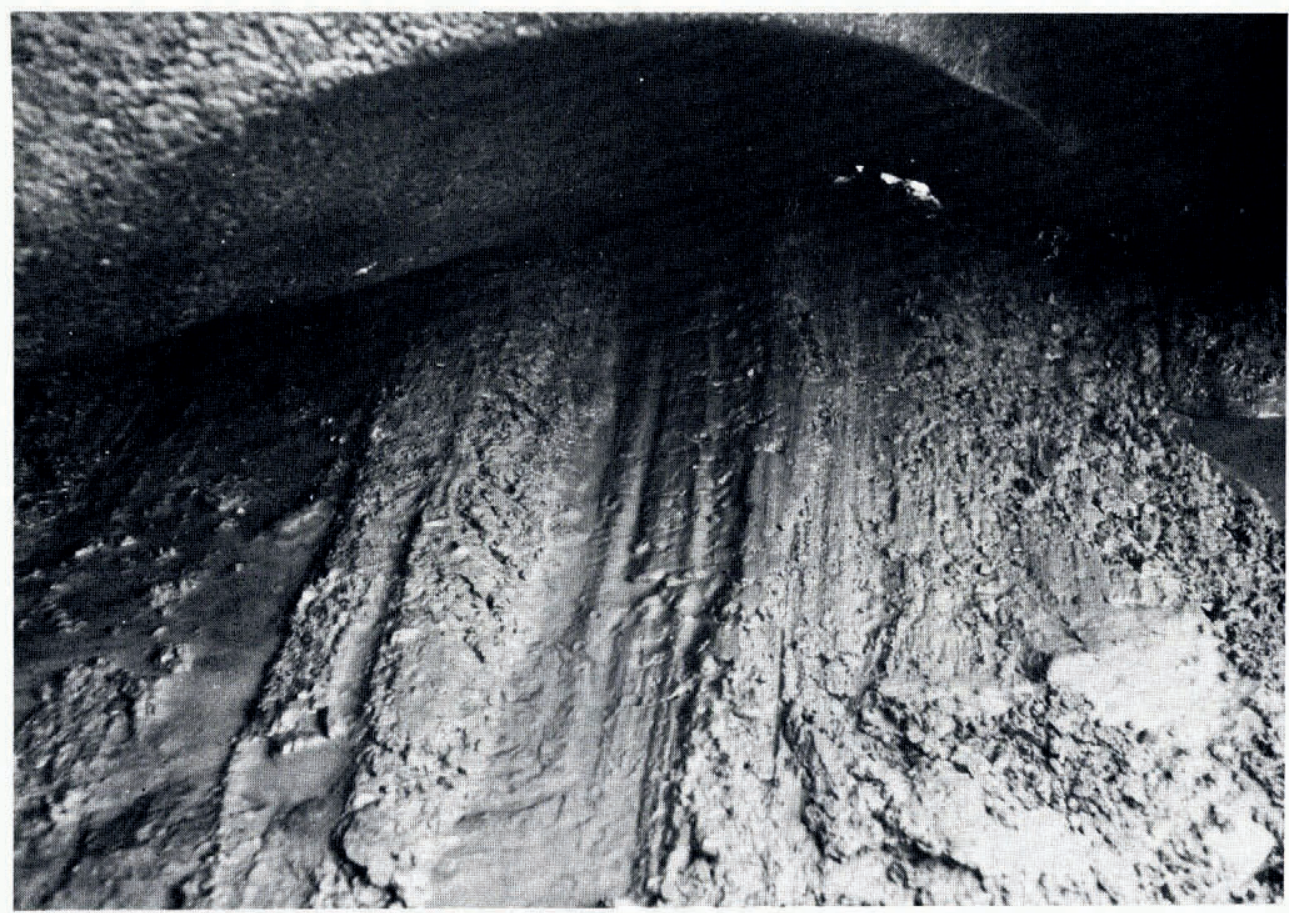

Fig. 7. Detail of fluted surface beneath marginal snow bank (Lucas Glacier); width on the photograph is approximately $1 \mathrm{~m}$.

\section{WHY "SNOW-BANK PUSH"?}

One of the significant facts concerning this ice-edge-snow-bank relationship is that it reveals something about the behaviour of the glacier margin which, unless it was continuously monitored, would not otherwise be known. A lack of data concerning the movement of the ice margin over short time intervals makes it difficult to interpret the processes responsible for many ice-contact forms. However, the widespread nature of marginal snow-bank disturbance suggests that during the accumulation season of 1974 there was a minor advance of the glacier termini. How valid is this statement in the light of glaciological evidence? Smith (196o, p. 708) noted that "heavy accumulation in winter and strong melting in summer are characteristic of glaciers in the cyclonic climatic zones". There is, therefore, a considerable likelihood that the glacier front will advance during the winter season. A possible reason for this is that, although during the summer the ice edge retreats due to the heavy melt, the ice mass itself does not cease to flow and the rate of ablation merely exceeds the rate of ice replacement at the margin. However, during the winter when the melt has ceased the situation is reversed and the ice edge will advance.

It is difficult to establish precisely when this forward movement takes place. The folding of the snow bank dates it as sometime after significant snow accumulations have developed at low altitudes. From the 1972 records for King Edward Point, this maximum did not occur until early September when the snow depth reached $105 \mathrm{~cm}$. At two ridge sites, excavations revealed partly decomposed elephant seal pups (Lucas Glacier western margin on beach, and Cook Glacier eastern margin on beach). Since pups are not born until early October, the glacial advance must post-date this time. It is therefore suggested that the marginal advance which creates these "snow-bank push" forms does not occur until late in the accumulation season. This time lag is what the overall evidence suggests, for otherwise the advance pre- 
dicted for even the slowest-moving glaciers would be much greater than the $\mathrm{I}-3 \mathrm{~m}$ range apparent at the beginning of the $1974-75$ ablation season. With this glacial advance, the debris lying beneath the ice-snow junction, already subject to the load of the ice and snow overburden, will move to occupy any areas of lower stress that develop. Thus, as the ice-snow junction up-arches, the till beneath will flow upwards under pressure causing superficial disturbance in the till beneath. (It should be noted that deep disturbance was not observed in any of the sections investigated but, since the amount of disturbance is clearly related to the dimensions of the ridge produced, larger examples of "squeeze" or "push" ridges may well involve deep-rooted movement of material.) This process has been deduced from the analysis of the till fabrics of several ridges formed in this manner. The clasts generally show a strong preferred orientation thought to be inherited from the parent till (i.e. the orientation is the same as the undisturbed till beneath); reflecting the ice direction. However, the data concerning their axial dips reveal significant rotation in the vertical plane. This type of fabric disturbance requires some form of discrete mass movement, like plug flow, which permits the retention of part of the property of the original fabric.

The glaciers in South Georgia have been retreating for the past $40-45$ years. This has permitted the development of large numbers of these "annual" moraine ridges within the fresh till areas. The variabiliy of the ice margin is such as to preclude accurate chronologies being fixed on the basis of the ridges alone. There is little doubt that each year a new ridge is formed at the ice margin where conditions suit but this may in turn cover an earlier one. Thus, although ridges may form annually, there may not be any correspondence between their numbers and the time span in which they have formed.

\section{Conclusion}

Interaction between the glacier edge and the marginal snow bank may result in the formation of a low till ridge, parallelling the former position of the ice edge at the beginning of the ablation season. This process of "snow-bank push" results in an extremely variable ridge form which rapidly loses its distinctive character, and soon becomes difficult to differentiate from ridges formed by alternative processes. The observations support Clapperton's (I97I) contention that moraine ridges may form by squeeze processes, examples of which were observed in operation.

\section{Acknowledgements}

The writer gratefully acknowledges the field assistance of the British Antarctic Survey, especially the crew of R.R.S. Fohn Biscoe and the base members at South Georgia. Particular thanks are due to J. D. Hansom and R. J. Timmis for their help in the field work, to Drs C. M. Clapperton and D. E. Sudgen for their helpful suggestions, and Dr A. M. D. Gemmell for his encouragement during preparation of the paper. The work was part of a geomorphological study programme in the Antarctic supported jointly by the Natural Environment Research Council and the British Antarctic Survey. Study facilities were provided by the Department of Geography, University of Aberdeen. Personal support was funded by N.E.R.C. grant No. GT4/74/GS/I.

\section{MS. received 3 October 1975 and in revised form 28 June 1976}

\section{REFERENCES}

Clapperton, C. M. 1971. Geomorphology of the Stromness Bay-Cumberland Bay area, South Georgia. British Antarctic Survey Scientific Reports, No. 70.

Smith, J. 1960. Glacier problems in South Georgia. Journal of Glaciology, Vol. 3, No. 28, p. 705-14.

Worsley, P. 1974. Recent "annual" moraine ridges at Austre Okstindbreen, Okstindan, north Norway. Journal of Glaciology, Vol. 13, No. 68, p. 265-77. 